\title{
ATLANTIS IN SPAIN
}

\section{Papamarinopoulos S.P.}

University of Patras, Department of Geology, Patra, Greece

\section{Part II: The case of prehistoric Athens}

\begin{abstract}
Plato, who lived in the $4^{\text {th }}$ century B.C., wrote the dialogue Timaeos and Critias when he was 52 years old. In this he describes a catastrophe in Athens from an earthquake in the presence of excessive rain. He also describes several details, not visible in his century, in the Acropolis of Athens. These details are a spring and architectural details of buildings in which the warriors used to live. In Critias he mentions that the destruction of the spring was caused by an earthquake. The time of the catastrophe of Atlantis was not defined by him but it is implied that it occurred after the assault of the Atlantes in the Mediterranean. Archaeological excavations confirmed the existence of the spring which was about $25 \mathrm{~m}$ deep with respect to the present day walking level. Archaeologically dated ceramics, found at its bottom, denote the last function of the spring was in very early $12^{\text {th }}$ century B.C. Plato describes the warriors' settlements which were found outside of the fortification wall in the North East of the Acropolis. The philosopher, who was not a historian, describes a general catastrophe in Greece from which the Greek language survived till his century. Archaeological studies have offered a variety of tablets of Linear B writings which turn out to be the non-alphabetic type of writing of the Greeks up to the $12^{\text {th }}$ century B.C. before the dark ages commence. Modern geoarchaeological and palaeoseismological studies prove that seismic storms occurred in the East Mediterranean between 1225 and 1175 B.C. The result of a fifty-year period of earthquakes was the catastrophe of many late Bronze Age palaces or settlements. For some analysts both Athens and Atlantis presented in Timaeos and Critias are imaginary entities. They maintained that the imaginary conflict between Athens and Atlantis served Plato to produce the first world's "science fiction" and gave the Athenians an anti-imperialistic lesson through his fabricated myth. However, a part of this "science fiction", Athens of Critias, is proved a reality of the $12^{\text {th }}$ century B.C., described only by Plato and not by historians, such as Herodotus, Thucydides and others. Analysts of the past have mixed Plato's fabricated Athens presented in his dialogue Republic with the non-fabricated Athens of his dialogue Critias. This serious error has deflected researchers from their target to interpret Plato's text efficiently.
\end{abstract}

\section{Introduction}

Plato at Critias is very specific when he presents the Acropolis of Athens. He describes several architectural elements and a particular spring. He is very clear mentioning an earthquake as the cause of the catastrophe of the spring. Apart of this, isolated event in Athens, he describes a general catastrophe in prehistoric Greece which made its people illiteral. He added the detail of giving Greek names to their off-springs. Undoubtedly he does not know when these events took place. He has the impression that all events are as old as the Egyptian priesthood mentioned to Solon. In other words he connects the assault of the Atlantes, the catastrophe of Athens and Greece at a remote time thousands of years before Solon's $6^{\text {th }}$ century B.C. Let us analyze the data and examine all the relevant passages in detail from his dialogues carefully versus the existing past scientific data. 


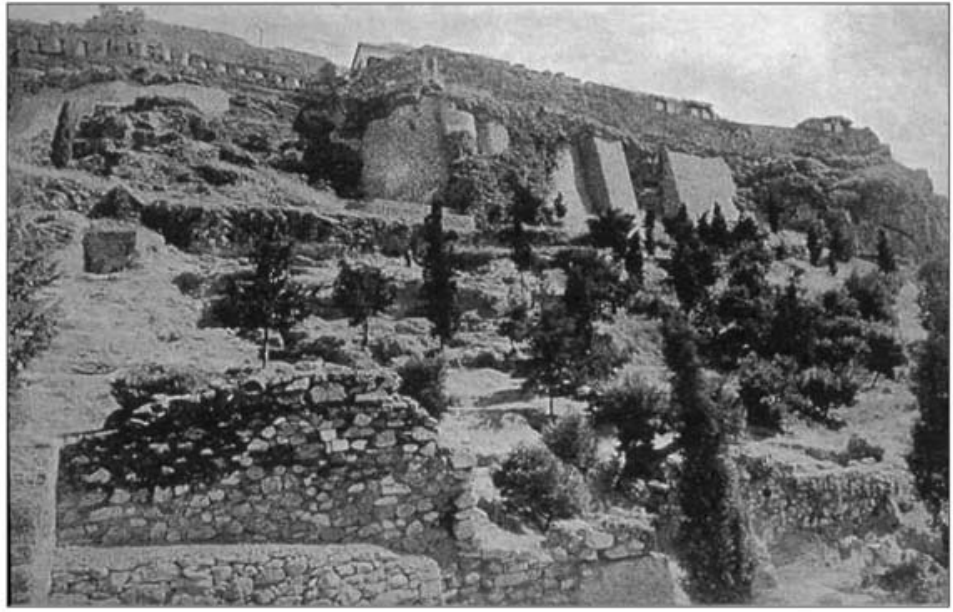

Fig. 1: The North bank of the Acropolis of Athens, (after Broneer, 1939).

\section{Plato's Confirmed Passages I}

\subsection{Details of prehistoric Athens and its catastrophe}

Many analysts of Plato's text in relation to Atlantis in the past (Ramage, Fears, Luce and Fredericks, 1978), (Gill, Forsyth-Gordon, 1980) and Vidal-Naquet, 2005) although recognized that Plato in the Republic did indeed present a fabricated myth of prehistoric Athens they did not manage to recognize that in Timaeos and Critias he presented a non-fabricated myth of the prehistoric Athens of the $12^{\text {th }}$ century B.C. The date is obtained from Plato's unique and detailed description of that past Athens. It is highly astonishing because the evidence existed in front of their eyes. They could receive it from Kavadias' (1897), Broneer's $(1939,1948)$ and Carpenter's $(1966)$ excellent studies. Vidal-Naquet (2005) who was a historian could not understand that Plato played in fact the role of a historian once too, offering unique information, without being able to reach ever the level of the enthusiastic Herodotus or even of the strict and careful Thucydides and the rest of the professional historians. Plato had a genuine interest in prehistory and he expressed it ignoring fully both Herodotus in connection with prehistoric Athens and the world affairs of the $12^{\text {th }}$ century B.C. Vidal-Naquet's model of imaginary Athens conflicting with the imaginary anti-Athens, in other words Atlantis, it does not work at all. Athens of Timaeos and Critias was a proved archaeological reality of the $12^{\text {th }}$ century B.C. completely unknown to the Athenians of the $5^{\text {th }}$ and $4^{\text {th }}$ centuries B.C. Gill's idea (1980) that Timaeos and Critias is a pastiche, in other words a mixture of historic with fictitious information could have a point to build an argument if he had established a rigid set of criteria independent which would allow him to remove fictitious from non-fictitious. But since 1897 we get more additional clarifying proofs for Plato's text. Let us follow these proofs carefully by following Plato's statements step by step. In order to do that, we need to visit Acropolis.

In Figure 1 the Northern Bank of the Athens Acropolis is shown.

Plato writes as follows in connection with the Acropolis: 


\section{Architectural details on Athens's prehistoric Acropolis}
Criti 112.b.3-112.b.5

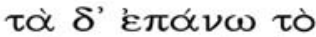

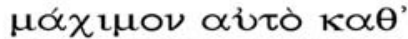

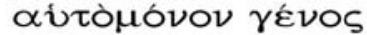

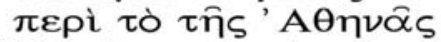

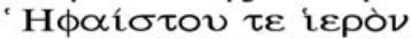

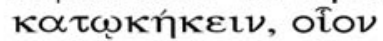

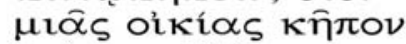 हvì $\pi \varepsilon \rho \iota \beta \sigma \lambda \omega$

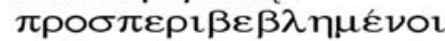

But on the topmost part only the military class by itself had its dwellings round about the temple of Athena and Hephaestus, surrounding themselves with a single ring-fence, which formed, as it were, the enclosure of single dwelling

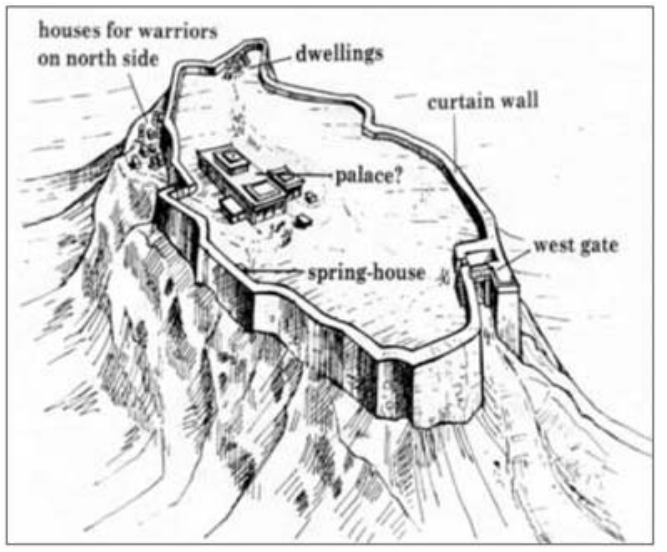

Fig. 2: The outlay of the Acropolis of Athens at the end of the prehistoric period (12 $2^{\text {th }}$ century B.C.). The warriors' houses are in the Northern bank of the Acropolis outside its walls. The spring is also indicated, as Plato describes it (after Castlenden, 1998).

\section{Winter compartments in the north}

\section{Criti 112.b.5-112.b.7 $\tau \propto \alpha \gamma \alpha \dot{\alpha} \pi \rho \delta \sigma \beta о \rho \rho \alpha$

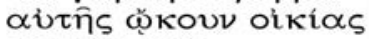

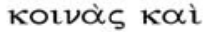

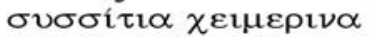 $\kappa \propto \tau \alpha \sigma \kappa \varepsilon v \propto \sigma \alpha ́ \mu \varepsilon v o r$,}

on the northward side of it they had established their public dwellings and winter mess-rooms,

\section{Summer compartments in the south}

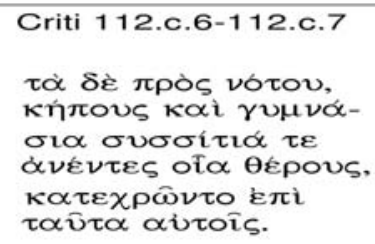

Criti 112.c.6-112.c.7

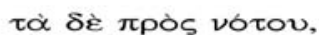

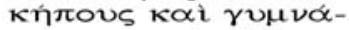

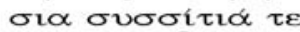

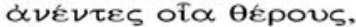

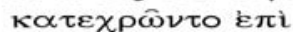

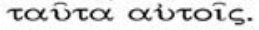

as for the southward parts, when they vacated their gardens and gymnasia and mess-rooms as was natural in summer 


\section{The guardians}

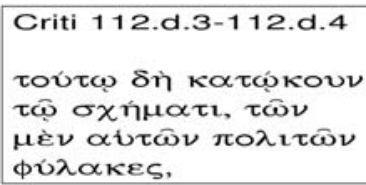

They dwelt, acting as guardians

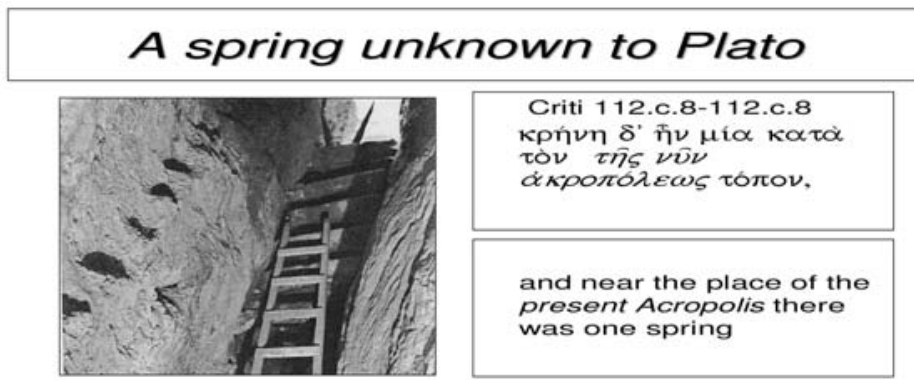

Fig. 3: The spring's entrance (after Travlos, 1971).

In our project we would like to send a visitor with a time machine in prehistoric Athens to climb up and come to the North part of Acropolis. He could see in early $12^{\text {th }}$ century B.C. the buildings of the guardians out side of the wall of the Acropolis as Plato described it in the $4^{\text {th }}$ century B.C. (Figure 2).

But if he could continue his tour in a particular sunny day of the summer of $1200 \mathrm{yr}$ B.C. on the Acropolis he would wonder where to find water to drink he would be amazed since on the Acropolis there was a subterranean entrance leading to stairs.

But he had to go down nearly $25 \mathrm{~m}$ as Figure 4 illustrates and there he would find cold water to drink.

\section{Seismic result on the spring}

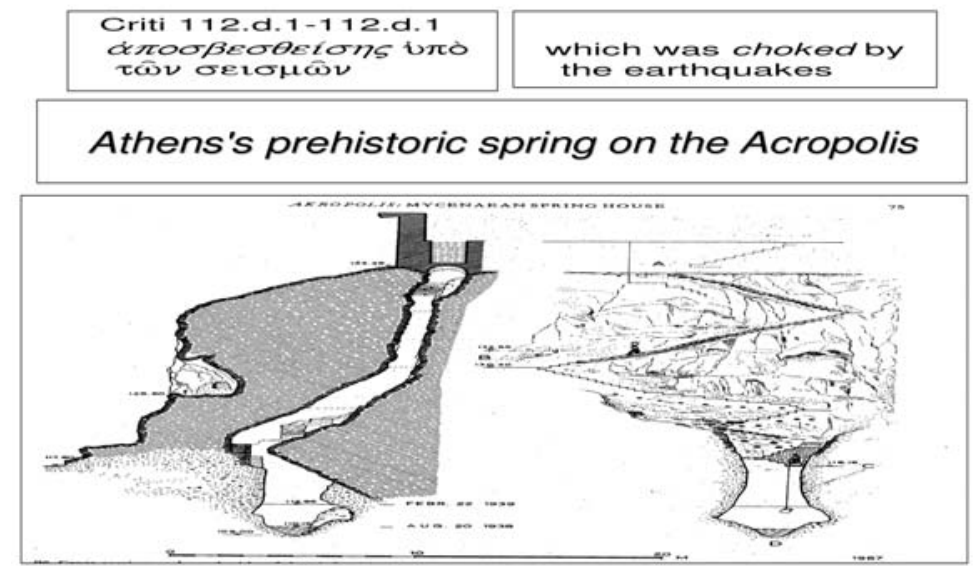

Fig. 4: The vertical section of the spring (after Broneer 1939 and after Travlos, 1971 respectively. 
But if the today's visitor had to visit the spring he would realize that it does not function any more. If he had geological knowledge and inspected not only the spring but all the area around Acropolis he would realize that an old earthquake had destroyed it. If by any chance could read Plato's text he would read the following:

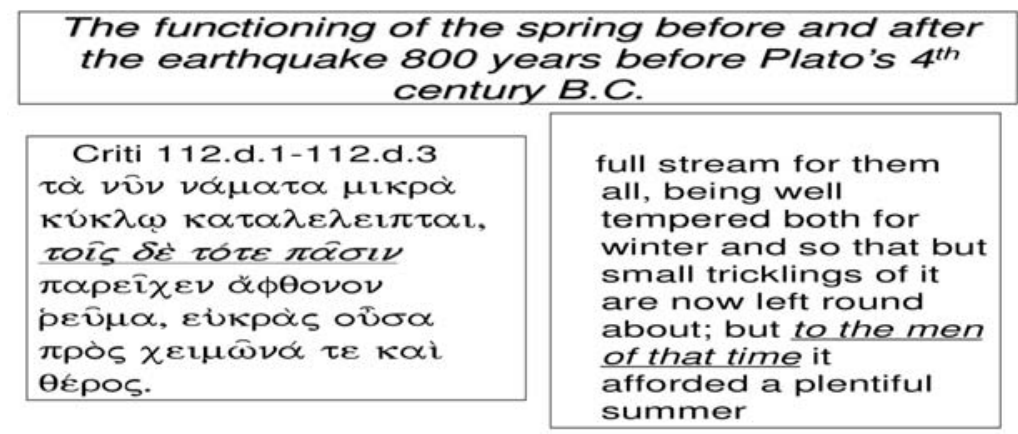

If he was curious enough he would discover in the nearby museum that there is pottery found in the bottom of the old spring. His broken pottery denotes the time of the occurrence of the earthquake which stopped the functioning of the spring. It was the very first part of the $12^{\text {th }}$ century B.C. as Plato once described in Critias 800 years before his period. But continuing reading Plato he would realize that he gives even further details of the functioning of the former spring.

Jordan (2001) uncritically says that Plato saw in the bank of the Acropolis the layer with the Mycenaean blocks and deduced the rest with the assistance of his fertile imagination! The question is applicable to Vital-Naquet (2005) as well who in his book said that Plato hated history! We used Jordan's book "The syndrome of Atlantis" which in Vidal-Naquet's opinion is complementary of his own "L'Átlantide" and we say that together with Edwin Ramage, who was editor and one of the authors of the volume of the proceedings of the symposium "Atlantis Fiction or Fact", could not see the following tangible evidence which Kavadias (1897) and Broneer (1939-1948) described. We invite them to read the following passage from Broneer's paper:

"Plato's description of early Athens is highly imaginative, as is the whole background for the dialogue of the Critias with the account of Atlantis and the tale of the war between the two powers. But is the whole story an invention on Plato's part, as modern philologists like to believe, or did he to some extent make use of material handed down by tradition and perhaps recorded by writers whose works are now lost? Whatever view we take of his statement that the account was first recorded by Solon who had received it from Egyptian priests, it must be admitted that if this story is his own invention it was framed as to appear plausible to Critias' interlocutors in the dialogue. We are justified in assuming that the main sketch of his picture of early Athens and of the buildings on the Acropolis is based on tradition and on accounts known to Plato and believed by him to be true. In Plato's days two important but not very copious springs existed on the slopes of the Acropolis, the Klepsydra on the northwest slope, and the spring in the Asklepeion on the south side, and possibly there were others which have since been covered over. It was natural for Plato and his contemporaries to connect these with the tradition of the one large spring in or near the Acropolis which was said to have dried up after an earthquake, and the inference was near at hand that the existing springs came into being as the natural result of this event. Actually there can be no direct connection between the destruction of the one and the origin of the 


\section{Survival of the Hellenic language}

\begin{tabular}{|c|c|}
\hline Criti 109. d.2-109.d.4 & \\
\hline 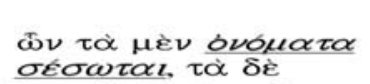 & $\begin{array}{l}\text { and of these citizens } \\
\text { the names are } \\
\text { preserved, but their }\end{array}$ \\
\hline 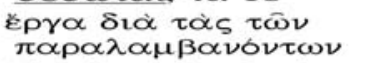 & $\begin{array}{l}\text { works have vanished } \\
\text { owing to the repeated }\end{array}$ \\
\hline 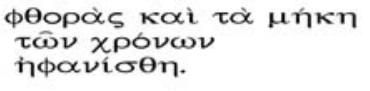 & $\begin{array}{l}\text { successors and the } \\
\text { length of the } \\
\text { intervening periods }\end{array}$ \\
\hline
\end{tabular}

\begin{tabular}{|c|c|}
\hline 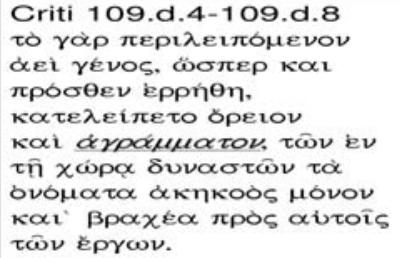 & $\begin{array}{l}\text { For, as was said } \\
\text { before, the stock that } \\
\text { survived on each } \\
\text { occasion was a } \\
\text { remnant of unlettered } \\
\text { mountaineers which } \\
\text { had heard the names } \\
\text { only of the rulers, and } \\
\text { but little besides of } \\
\text { their work }\end{array}$ \\
\hline
\end{tabular}

\section{The lady of the winds}

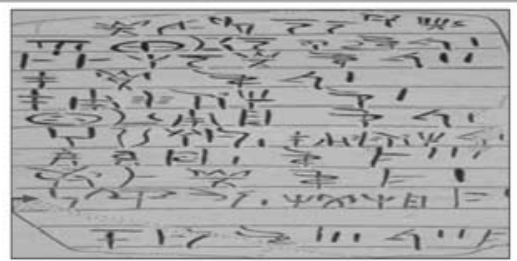

Fig. 5: The Greek writing system of Linear B. The ideographic symbols of a slightly different colour, in the line before the bottom line, mean "the Lady of the winds".

others, for it is likely that the springs on the slopes existed in some form even earlier than the main made fountain on the Acropolis. But tradition centered about the latter, which at one time in the history of the city had been of such importance to the lives of the inhabitants. It can hardly be doubted that this spring, whose existence was all but forgotten to the Athenians of the fifth century B.C. is the very fountain discovered in our excavations. As the earliest artificial water supply of ancient Athens it occupies a unique position among the scanty remains of that remote period."

We wonder what is the syndrome from which Jordan and Vidal-Naquet suffer which did not allow them to see even these unique platonic information about Critias' prehistoric Athens of the $12^{\text {th }}$ century B.C. which are proved historic facts?

\section{Plato's Confirmed Passages II}

\subsection{The illiteral Greeks and the dark ages}

But Plato continues and he describes the end of the Achaean culture in Greece and the consequences of the dark ages. He offers new and unique additional information which both Herodotus and the rest of the historians missed entirely. He says literally that the names of the prehistoric Greeks were saved in spite of the loss of their works! 
Plato mentions that the prehistoric Greeks became illiteral.

He also writes that the later Greeks, loving their linguistic heritage, gave Greek names to their children. In Figure 5, a Linear B writing example of the Greek language is shown. The symbols at the base of the gray frame, mean the lady of the winds in alphabetic Greek.

Plato describes characteristically the Greeks' love in their linguistic heritage with the following way:
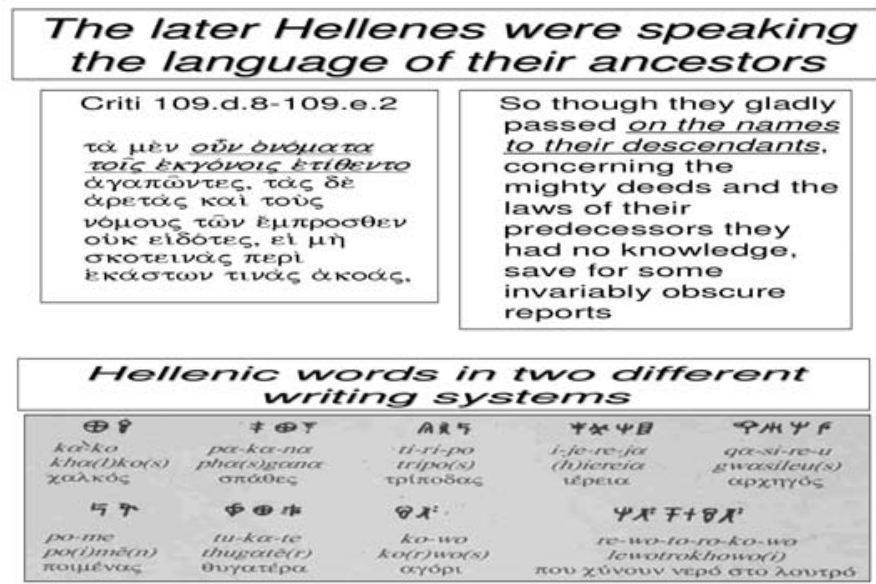

Fig. 6: Common words in Linear B, as found in Greece in the Achaean period (up to the $12^{\text {th }}$ century B.C.) and alphabetic Greek writing symbols (from the $9^{\text {th }}$ century B.C. on wards).

Figure 6 illustrates an example of Greek words in both Linear B and alphabetic Greek writing systems presented in Latin characters.

It is obvious that Carpenter (1966) correctly noted that Plato was the only one who described the survival of the Greek language after the catastrophe of the $12^{\text {th }}$ century B.C. Greek language was written in Linear $\mathrm{B}$ form, for centuries, before the $12^{\text {th }}$ century B.C. during the Achaean period. It was forgotten during the dark ages every where, except Cyprus, and it was rewritten in alphabetic Greek in the $9^{\text {th }}$ century B.C.

The $9^{\text {th }}$ century B.C. is the century confirmed by Herodotus and by numerous archaeological excavations in Italy, Greece and Asia Minor. We invite the authors of the symposium held at Indiana University in 1978 about Atlantis and Jordan and Vidal-Naquet to read Carpenter's publication again who wrote the following statement:

"I am aware that, as F.M. Cornford remarked in his edition of Plato's cosmology, serious scholars now agree that Atlantis probably owed its existence entirely to Plato's imagination”.

Carpenter continues further saying the following:

"A remarkable detail that should convince the most skeptical of the genuineness of Solon's conversation with the Saitic priests is the latter's unambiguous statement that the older Greek race had been reduced to an unlettered and uncivilized remnant which, like children, had to learn its letters anew. This claim we know to be entirely exact; but we have no reason to believe that Plato himself was aware of it."

But what was the cause of the catastrophe which made the Achaean culture to vanish? We have presented in these proceedings another cause, one from several in fact, of this destruction Papamarinopoulos (2007a). It is time to present another cause which links us with Plato's text once more. Nur and Cline (2000) have discussed the case of the seismic storms which hit for fifty years Eastern Mediterranean. They present in 
Figure 7 a map which exhibits the size of the effect of the seismic storm. They numbered 47 sites starting from Dymaeon Teichos (No1) in Greece and finished with Ashkelon (No47) in Middle East. They claimed that between 1225 and 1175 B.C. the earthquakes destroyed all these late Bronze Age settlements. However, for some reason not understood they missed Athens! In this Figure we set Athens with No0 thus making 48 the sites experienced the seismic storm and added No35 at the marked point. By doing that we say to the reader that Plato once more writes the truth and in particular he presents part of the turbulent reality of the $12^{\text {th }}$ century B.C. from the standpoint of the Achaean prehistoric Athens. His work was not a small story as Vidal-Naquet (2005) erroneously suggested. The reader may see that in No13 Troy is within the list. In other words Homer is justified too saying the following:

\section{A torrential rain, a seaquake and a tsunami in the $12^{\text {th }}$ century B.C. described by Homer}
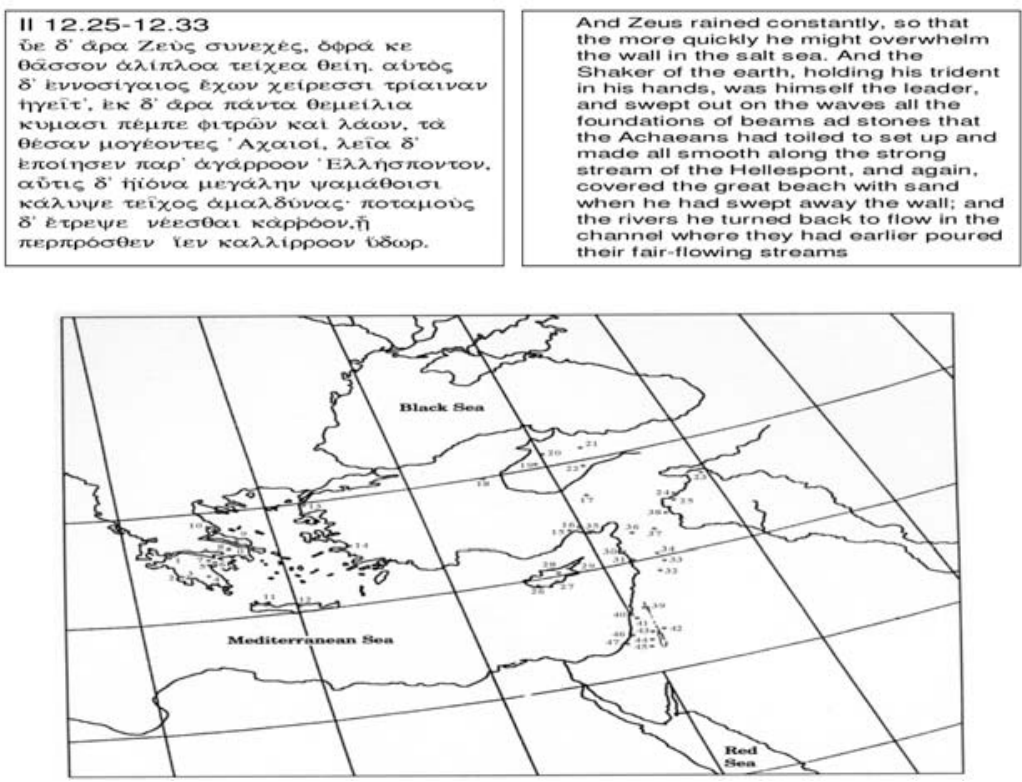

Fig. 7: Both ancient authors, Plato and Homer, retained a different, but complementary, tradition of the $12^{\text {th }}$ century B.C. The author of the present paper has completed Nur's and Cline's (2000) map of the seismic hazards in the East Mediterranean in the $12^{\text {th }}$ century B.C. Modern science offers a full picture of the results of the seismic storms in the East Mediterranean by marking Athens as 0 . Ancient prehistoric tradition in Greece, originating from the $12^{\text {th }}$ century B.C. has been separately retained for Athens and Troy shown in 0 and 13 respectively.

Homer describes a double event which was expressed initially as exceptional rain followed by a seaquake in the Hellespont producing a tsunami which entered in the Troad and destroyed the Achaean camp. Since we do not know where the Achaean camp was, we observe that $12^{\text {th }}$ century B.C. seismic activity at Troy itself which was most likely close to the Achaean camp. The archaeologically proved seismic event at Troy, mentioned by Nur and Cline (2000), was described by the excavators too in their final report:

"We feel confident in attributing the disaster to a severe earthquake", "a violent earthquake shock will account more convincingly than any probable human agency for the toppling of the city wall" Nur and Cline (2000) say that the event has occurred in the period between 1225 and 1175 B.C.

But Plato describes something very similar in connection with Athens as follows: 


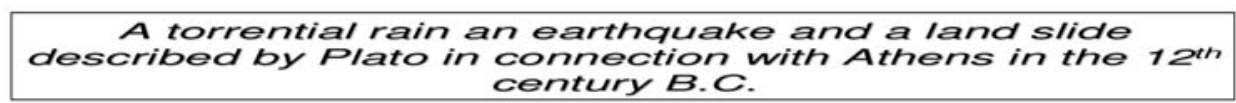

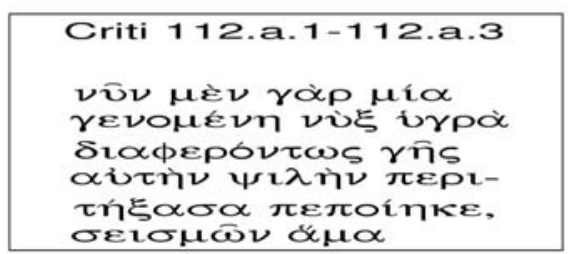

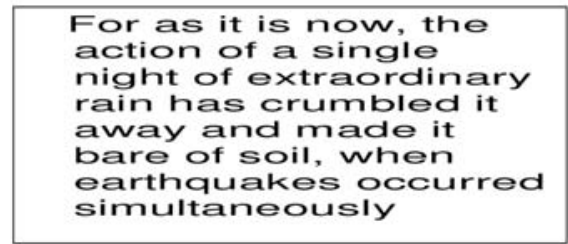

Fig. 8: The major faults of the East Mediterranean which are responsible for the seismic activity (after Nur and Cline, 2000).

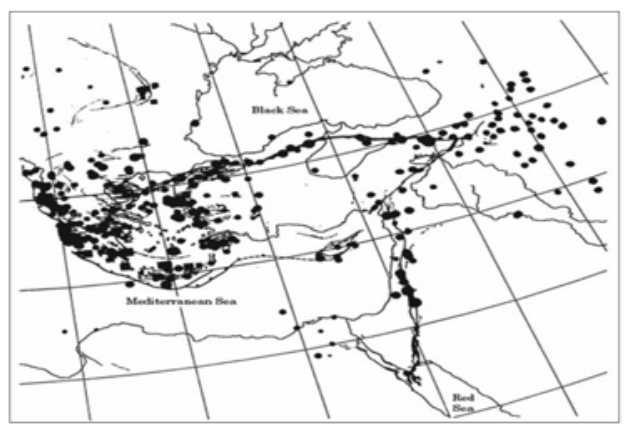

Fig. 9: The seismic epicenters of the East Mediterranean. over the last century. They are produced by earthquakes with a magnitude above 6.5 Richter. They are instrumentally recorded over the twentieth century (after Nur and Cline, 2000).

We know that the seismic event of the Acropolis was recorded because it stopped the subterranean spring in early $12^{\text {th }}$ century B.C. Plato himself does not know the date of the event thus he tries to connect it, convinced by the Egyptian priesthood, with the oldness of Athens, Atlantis and Egypt in the range of thousands of years, by putting the Athenian event earlier than occurrence of Deucalion's well known flood. By placing prehistoric Athens in the map, produced by Amos and Nur, we also say that Troy and Athens were destroyed "simultaneously" so to speak in other words due to the seismic storms within the fifty years (1225-1175 B.C.) period. Figure 8 illustrates the position of the major faults in East Mediterranean.

Figure 9 shows the epicentres of earthquakes with magnitudes 6.5 Richter in East Mediterranean the last 100 years recorded instrumentally.

\section{Conclusions}

Homer and Plato present seismic catastrophes in Troy and Athens respectively which have been confirmed to have occurred within $12^{\text {th }}$ century B.C. 


\section{References}

Broneer, O., 1939. A Mycenaean fountain on the Athenian acropolis, Hesperia 8, p.p. 317-429.

Broneer, O., 1948. What happened at Athens, American Journal of Archaeology 52, p.p. 111-124.

Carpenter, R., 1966. Discontinuity in Greek civilization. Cambridge University press, p.p. 80.

Castlenden, R., 1998. Atlantis destroyed. Routledge, p.p. 225.

Cornford, F. MacDonald, 1937. Plato's cosmology. (London: Kegan Paul, Trench, Trubner and Co).

Kavadias, P., 1897. Ephemeris, p.28

Homer $8^{\text {th }}$ century B.C. The Iliad. Georgiadis, p.p. 800.

Jordan, P., 2001. The Atlantis syndrome. Sutton publishing, p.p. 308.

Nur, A. and Cline, 2000. Poseidon's horses: Plate tectonics and earthquake storms in the Late Bronze Age Aegean and Eastern Mediterranean, 27, p.p.47-63.

Papamarinopoulos, St. P., 2007a. Phaethon or Phaethousa. A shining comet in the $12^{\text {th }}$ century B.C.? Proceedings of the Melos symposium of $11^{\text {th }}-14^{\text {th }}$ of July 2005. The Atlantis Hypothesis: Searching for a Lost land.

Plato $4^{\text {th }}$ century B.C. Critias. Kaktos, p.p. 330.

Ramage, E. S., 1978. Atlantis-Fact or Fiction? Indiana University press.

Travlos, J., 1971. Pictorial Dictionary of Ancient Athens, London, p.72.

Vidal-Naquet, P., 2005. L'Atlantide. Les Belles Lettres, p.p.198.

Zangger, E., 1992. The flood from heaven. Deciphering the Atlantis legend. Sidgwick and Jackson Limited, p.p. 256. 